\title{
Detection and epidemic dynamic of ToCV and CCYV with Bemisia tabaci and weed in Hainan of China
}

\author{
Xin Tang ${ }^{1,2+}$, Xiaobin Shi ${ }^{2+}$, Deyong Zhang ${ }^{2}$, Fan Li ${ }^{3}$, Fei Yan ${ }^{4}$, Youjun Zhang ${ }^{5}$, Yong Liu ${ }^{2 *}$ and Xuguo Zhou ${ }^{1,6^{*}}$
}

\begin{abstract}
Background: In recent years, two of the crinivirus, Tomato chlorosis virus (ToCV) and Cucurbit chlorotic yellows virus (CCYV) have gained increasing attention due to their rapid spread and devastating impacts on vegetable production worldwide. Both of these viruses are transmitted by the sweet potato whitefly, Bemisia tabaci (Gennadius), in a semipersistent manner. Up to now, there is still lack of report in Hainan, the south of China.

Methods: We used observational and experimental methods to explore the prevalence and incidence dynamic of CCY and ToCV transmitted by whiteflies in Hainan of China.

Results: In 2016, the chlorosis symptom was observed in the tomato and cucumber plants with a large number of $B$. tabaci on the infected leaves in Hainan, China, with the incidence rate of $69.8 \%$ and $62.6 \%$ on tomato and cucumber, respectively. Based on molecular identification, Q biotype was determined with a viruliferous rate of $65.0 \%$ and $55.0 \%$ on the tomato and cucumber plants, respectively. The weed, Alternanthera philoxeroides near the tomato and cucumber was co-infected by the two viruses. Furthermore, incidence dynamic of ToCV and CCV showed a close relationship with the weed, Alternanthera philoxeroides, which is widely distributed in Hainan.

Conclusion: Our results firstly reveal that the weed, A. philoxeroides is infected by both ToCV and CCYV. Besides, whiteflies showed a high viruliferous rate of ToCV and CCY. Hainan is an extremely important vegetable production and seed breeding center in China. If the whitefly can carry these two viruses concurrently, co-infection in their mutual host plants can lead to devastating losses in the near future.
\end{abstract}

Keywords: Tomato chlorosis virus; cucurbit chlorotic yellows virus; Bemisia tabaci, Molecular identification, Q biotype, Alternanthera philoxeroides

\section{Background}

Plant virus causes serious threat in the growth and product of crops and vegetables in the world [1]. Plant viruses depend on insect vectors for transmission in a non-persistent, semi-persistent and persistent manner, respectively [2]. The prevalence of plant viruses is closely related to the dynamics of insect vectors $[3,4]$.

\footnotetext{
* Correspondence: haoasliu@163.com; xuguozhou@uky.edu

${ }^{\dagger}$ Equal contributors

${ }^{2}$ Hunan Academy of Agricultural Science, Hunan Plant Protection Institute, Key Laboratory of Pest Management of Horticultural Crop of Hunan Province, No. 726, Yuanda Road, Furong District, Hunan province, Changsha 410125, China

${ }^{1}$ College of Plant Protection, Hunan Agricultural University, Changsha 410125, China

Full list of author information is available at the end of the article
}

The whitefly, Bemisia tabaci (Gennadius) (hemiptera; Aleyrodidae) is a main vector for plant virus transmission in greenhouse, which has rapidly increased all over the world followed by outbreaks of whitefly-transmitted viruses, causing great losses in agricultural production [5-7]. The most destructive vector in China is B. tabaci B (MEAM1) and Q (MED) [8]. B. tabaci B has been documented in China since the mid-1990's, but Tomato yellow leaf curl virus (TYLCV) was not detected until Q became established in $2003[9,10]$, and epidemic of TYLCV is associated with the increasing number of $Q$ $[10,11]$. Plant virus can be transmitted by whiteflies in a persistent or semi-persistent manner. Up to now, most research has been focused on the persistenttransmitted virus such as TYLCV but less attention is 
paid on semi-persistent transmitted viruses. To note, research on the relationship between epidemiology of the crinivirus and whitefly is important to prevent virus outbreak.

Tomato chlorosis virus (ToCV), genus crinivirus, family closteroviridae [12], is transmitted by $B$. tabaci in a semi-persistent manner $[1,13]$. The disorder and yellow symptoms such as the interveinal chlorosis, the leaf brittleness, and the limited necrotic flecking can be used to determine the virus $[1,14,15]$. ToCV was first reported in Florida [16], and then it transmitted to Spain [17], Africa [18, 19], the Middle East [17], and Asia [20, 21]. ToCV can be infected in 24 species of 7 family plants [1]. In Spain Q whiteflies has been determined on ToCV-infected leaves [17]. In Costa Rica Q whiteflies has also been detected on ToCV-infected leaves [22]. In China ToCV was first found in Taiwan [23], and then was found in Shandong [21] and many other northern places, such as Shanxi, Beijing and Neimenggu [24]. Up to now, there is still lack of report in the south of mainland China such as Hainan. With the increasing number of whiteflies in recent years, the potential threat should be noticed.

Cucurbit chlorotic yellows virus (CCYV) belongs to genus crinivirus, family closteroviridae [25]. CCYV can cause chlorotic leaf spots and yellowing of leaves in pumpkin, melon, watermelon, and tobacco $[25,26]$. CCYV is transmitted by B. tabaci B and Q in a semipersistent manner. It was first determined in Japan in 2010 [27], and then it was found in China [28], Sudan
[29], Greece [30] and Iran [31]. CCYV was also found in many northern places in China, such as Beijing, Hebei, and Anhui provinces (unpublished data). There is still lack of reports on whitefly biotype detection on virusinfected plants, which has an important role in research of the relationship between epidemiology of the crinivirus and whitefly.

In this research, we found the severe typical chlorotic symptoms on tomato and cucumber in many vegetable growing areas in Hainan province-the south of China. We found that numerous whiteflies gathered on infected plant leaves in cultivated places. We then collected the whiteflies and infected leaves with typical symptoms and then brought them into laboratory to detect the whitefly biotype and to determine the virus. ToCV and CCYV were identified, and B. tabaci Q was determined in all infected leaves. The weeds, Alternanthera philoxeroides nearby were also collected and determined, and the dynamics of ToCV and CCYV were then determined on tomato, cucumber and weeds in four growth stages in Yongfazhen where ToCV and CCYV showed a high virus incidence. Our results provide a basis for monitoring and prevention of viral diseases.

\section{Methods}

\section{Field survey}

To determine the incidence of the chlorosis disease in tomato and cucumber crops, a survey was undertaken in the Hainan province. Five sites (Yunlongzhen, Xinzhuzhen,

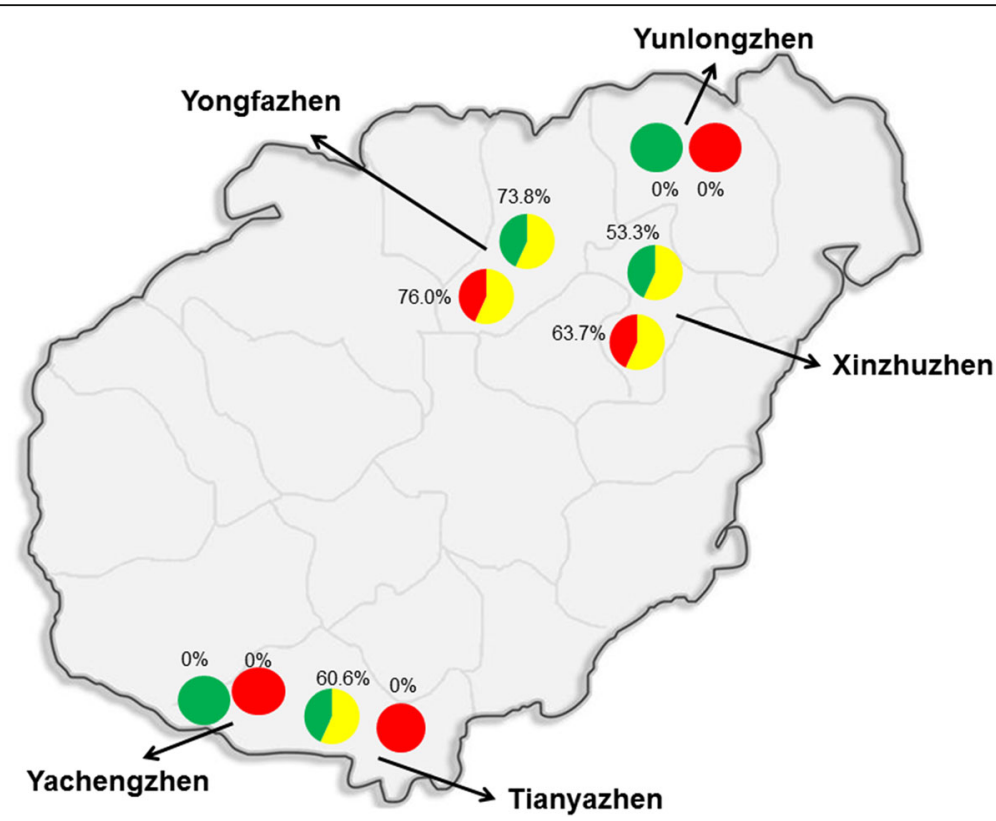

Fig. 1 Geographic locations of surveyed plants. Five sites in Yunlongzhen, Yongfazhen, Xinzhuzhen, Yachengzhen, and Tianyazhen were shown in the figure. In each site tomato and cucumber plants were investigated and sampled. Red circles and sectors represent tomato plants. Green circles and sectors represent cucumber plants. Yellow sectors represent virus-infected tomato and cucumber plants 
Yongfazhen, Tianyazhen, and Yachengzhen), representing the main vegetable-growing areas were surveyed (Fig. 1). For each site, over 200 to 300 plants including tomato and cucumber were surveyed and the incidence of the chlorosis disease was calculated. At each site, the chlorosis tomato and cucumber plants were selected and taken to the laboratory for molecular detection. Meanwhile, whiteflies on the symptomatic plants were collect randomly with aspirating equipment and taken to the laboratory for molecular detection.

\section{Whitefly biotype and viruliferous rate detection}

The whitefly samples were divided into four parts, of which two parts were used to detect the whitefly biotype on tomato and cucumber, and the other two parts were used to detect the viruliferous rate of ToCV and CCYV. The whitefly biotype was detected using the CAPS-cleavage amplified polymorphic sequence of mitochondrial cytochrome oxidase I gene ( $m t C O I)$ with the restriction endonuclease AseI [32]. The viruliferous rate detection method was described in section of virus detection in plants. In each part, 20 whiteflies were detected, and each of the detection was repeated three times.

\section{RNA extraction and reverse transcription from infected leaves}

Total RNA was extracted separately from $0.1 \mathrm{~g}$ infected tomato and cucumber leaves using the total RNA extraction kit (Tiangen Biotech, Beijing, China) following the manufacturer's instruction. Each of 20 samples was extracted from tomato and cucumber respectively. Each of the detection was repeated three times. Reverse transcription of RNA from the total nucleic acid extracts was performed using cDNA
Table 1 Primers of the ToCV, CCYV and whitefly

\begin{tabular}{lll}
\hline Name & Primer & Sequence \\
\hline ToCV & F & AAACTGCCTGCATGAAAAGTCTC \\
& R & GGTTGGATITGGTACTACATTCAGT \\
CCY & $F$ & CGCAATCAATAAGGCGGCGACC \\
& R & ACTACAACCTCCCGGTGCCAACT \\
Whitefly & $F$ & TTGATTITTGGTCATCCAGAAGT \\
& $R$ & CTGAATATCGRCGAGGCATTCC \\
\hline
\end{tabular}

synthesis kit (Takara, Beijing, China), following the manufacturer's instruction.

\section{Virus detection in plants}

ToCV detection: We selected 60 chlorosis tomato leaves for detection, of which 20 leaves were detected each time, and all the leaves were detected for 3 times. Reverse transcript-polymerase chain reaction (RT-PCR) was carried out using the primers designed in the HSP70h gene of ToCV using Primer Premier 5 software (Table 1). The PCR of ToCV was performed in $20 \mu \mathrm{l}$ of reaction mixtures containing $7 \mu \mathrm{l}$ of $\mathrm{ddH}_{2} \mathrm{O}, 10 \mu \mathrm{l}$ of mix, $1 \mu \mathrm{l}$ of each primer, and $1 \mu \mathrm{l}$ of cDNA. The PCR procedures are as follows: initial denaturation at $94{ }^{\circ} \mathrm{C}$ for $2 \mathrm{~min}$, followed by 35 cycles of $94{ }^{\circ} \mathrm{C}$ for $15 \mathrm{~s}, 56{ }^{\circ} \mathrm{C}$ for $30 \mathrm{~s}$ and $72{ }^{\circ} \mathrm{C}$ for $30 \mathrm{~s}$, and a final elongation step at $72{ }^{\circ} \mathrm{C}$ for $10 \mathrm{~min}$. The PCR products of ToCV were obtained and then separated by electrophoresis using 1.0\% agarose gels.

CCYV detection: We selected 60 chlorosis cucumber leaves for detection, of which 20 leaves were detected each time, and all the cucumber leaves were detected for 3 times. The PCR of the cucumber samples was carried out using the primers designed in the coat protein (CP) gene of CCYV using Primer Premier 5 software (Table 1). The PCR of CCYV was performed in $20 \mu \mathrm{l}$ of

Table 2 Incidence of ToCV and CCY

\begin{tabular}{|c|c|c|c|c|c|c|}
\hline Virus & Host plants & Geographic locations & $\begin{array}{l}\text { Number of } \\
\text { plants surveyed }\end{array}$ & $\begin{array}{l}\text { Number of } \\
\text { infected plants }\end{array}$ & $\begin{array}{l}\text { Incidence of } \\
\text { chlorosis disease (\%) }\end{array}$ & $\begin{array}{l}\text { Average incidence } \\
\text { of chlorosis disease (\%) }\end{array}$ \\
\hline \multirow[t]{5}{*}{ ToCV } & Tomato & Yunlongzhen & 145 & 0 & 0.0 & 69.8 \\
\hline & & Xinzhuzhen & 146 & 93 & 63.7 & \\
\hline & & Yongfazhen & 154 & 117 & 76.0 & \\
\hline & & Yachengzhen & 165 & 0 & 0.0 & \\
\hline & & Tianyazhen & 150 & 0 & 0.0 & \\
\hline \multirow[t]{5}{*}{ CCYV } & Cucumber & Yunlongzhen & 92 & 0 & 0.0 & 62.6 \\
\hline & & Xinzhuzhen & 90 & 48 & 53.3 & \\
\hline & & Yongfazhen & 84 & 62 & 73.8 & \\
\hline & & Yachengzhen & 66 & 40 & 60.6 & \\
\hline & & Tianyazhen & 81 & 0 & 0.0 & \\
\hline ToCV & Weed & Yongfazhen & 60 & 9 & 15.0 & 15.0 \\
\hline CCYV & Weed & Yongfazhen & 60 & 7 & 11.7 & 11.7 \\
\hline
\end{tabular}




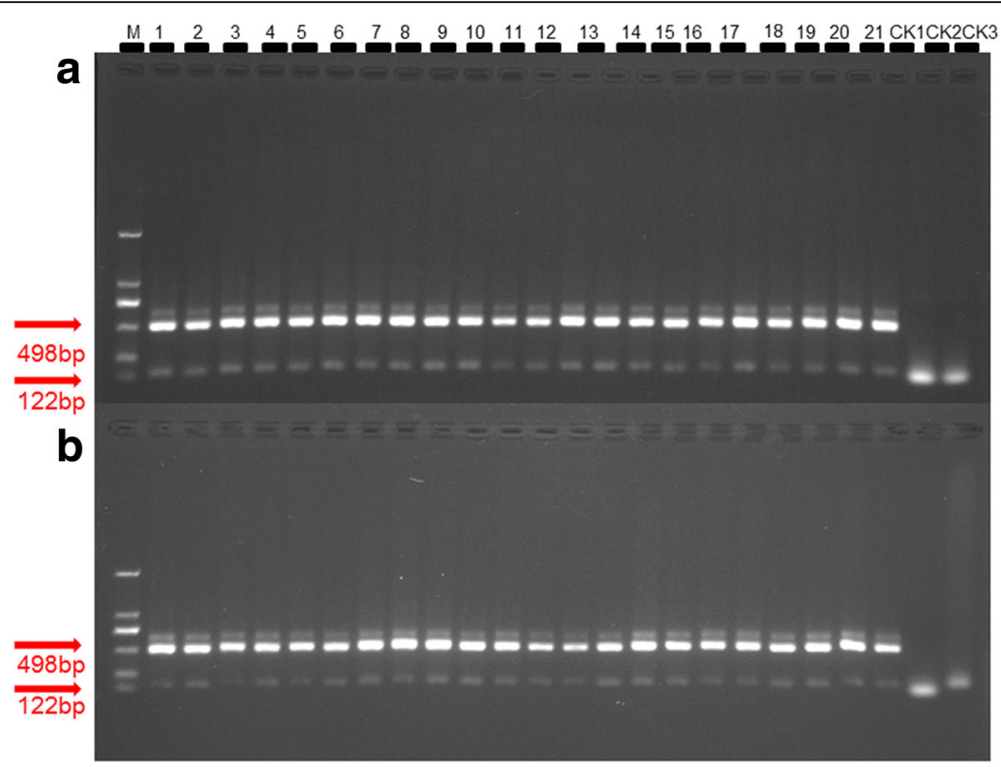

Fig. 2 Whitefly biotype detection. CK1 positive control; CK2 negative control; CK3 black control. a Whitefly biotype on infected tomato plants. b Whitefly biotype on infected cucumber plants. The size of $122 \mathrm{bp}$ and $498 \mathrm{bp}$ fragment based on amplification of mtCO/ and restriction endonuclease was used to detect the biotype. Results of 20 samples were shown in figure $\mathbf{a}$ and $\mathbf{b}$

reaction mixtures including $7 \mu \mathrm{l}$ of $\mathrm{ddH}_{2} \mathrm{O}, 10 \mu \mathrm{l}$ of mix, $1 \mu \mathrm{l}$ of each primer, and $1 \mu \mathrm{l}$ of cDNA. The PCR procedures are as follows: initial denaturation at $94{ }^{\circ} \mathrm{C}$ for $5 \mathrm{~min}$, followed by 35 cycles of $94{ }^{\circ} \mathrm{C}$ for $15 \mathrm{~s}, 53{ }^{\circ} \mathrm{C}$ for $30 \mathrm{~s}$ and $72{ }^{\circ} \mathrm{C}$ for $1 \mathrm{~min}$, and a final extension at $72{ }^{\circ} \mathrm{C}$ for $10 \mathrm{~min}$. The PCR products of CCYV were obtained and then separated by electrophoresis using $1.0 \%$ agarose gels.

ToCV and CCYV detection on weeds: In Yongfazhen, where ToCV and CCYV were detected with a high incidence, we collected the weeds, $A$. philoxeroides which are close to the infected tomato and $\mathrm{cu}$ cumber to detect ToCV and CCYV. We collected 60 weed leaves for detection of ToCV and CCYV in three replicates.

\section{Nucleotide sequencing analysis}

The target PCR products were purified by the AxyPrep DNA gel extraction kit (Axygen, Zhejiang, China), following the manufacturer's instructions. The purified products were then sequenced at the Sangon biotech (Shanghai, China). The sequence data of the whiteflies, ToCV and CCYV on tomato, cucumber and weeds were analysed using the BioEdit software. Sequences were compared with the NCBI nucleotide database via the BLAST tools on NCBI online server.

Virus incidence dynamic on tomato, cucumber and weeds The incidence dynamics of ToCV and CCYV were determined on tomato, cucumber and the weeds nearby: In four growth stages, transplanting, seedling, flowering and ripening of tomato and cucumber, plants were collected to our lab to detect the viruliferous rate of ToCV and CCYV. The weed, A. philoxeroides that was grown near the tomato and cucumber plants was also collected to detect the viruliferous rate of ToCV and CCYV. In each of the five sites of Yongfazhen where ToCV and CCYV were detected with a high incidence, 100 tomato leaves were collected for detection of $\mathrm{ToCV}$, and $100 \mathrm{cu}-$ cumber leaves were collected for detection of CCYV. The tomato plants and cucumber plants were adjacent, therefore 100 weed leaves nearby were collected for detection of ToCV and CCYV. That is to say, 500 tomato leaves, 500 cucumber leaves and 500 weed leaves were collected in one growth stage.

Table 3 Whitefly biotype and viruliferous rate

\begin{tabular}{lllll}
\hline Virus & $\begin{array}{l}\text { Number of } \\
\text { whiteflies }\end{array}$ & $\begin{array}{l}\text { Whitefly } \\
\text { biotype }\end{array}$ & $\begin{array}{l}\text { Number of } \\
\text { viruliferous } \\
\text { whiteflies }\end{array}$ & Viruliferous rate \\
\hline ToCV & 60 & Q & 39 & $65.0 \%$ \\
CCYV & 60 & $\mathrm{Q}$ & 33 & $55.0 \%$ \\
\hline
\end{tabular}




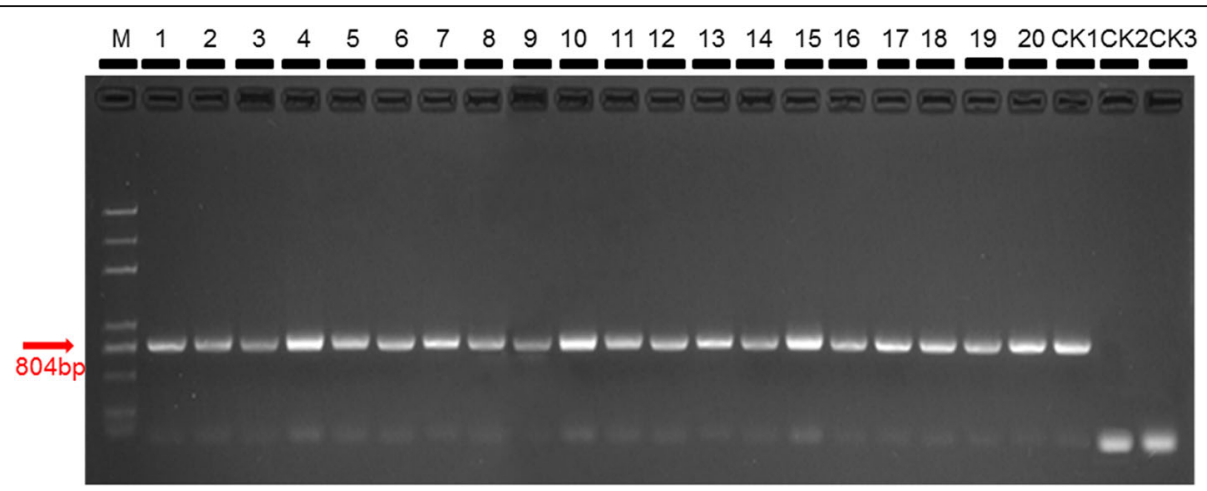

Fig. 3 ToCV detection from tomato plants. CK1 positive control; CK2 negative control; CK3 black control. The size of 466 bp based on amplification of HSP7Oh gene of ToCV was used. Results of 20 samples were shown in this figure

\section{Data analysis}

Statistical analyses were performed with SPSS (version 19.0, Chicago, IL, USA). One-way ANOVA was used to compare the viruliferous rate of plants in different growth stages and weeds.

\section{Results}

\section{Incidence of chlorosis disease}

The total number of 300 tomato plants and 240 cucumber plants was count in infected places of Xinzhuzhen, Yongfazhen and Yazhouzhen to calculate the virus incidence. The total number of 210 tomato plants and 150 cucumber plants was observed to show chlorosis symptom, with the average incidence of $69.8 \%$ and $62.6 \%$, respectively (Fig. 1, Table 2). In Yongfazhen, the viruliferous rate of ToCV and CCYV on the weed was $15.0 \%$ and $11.7 \%$, respectively (Fig. 1 , Table 2 ).

\section{Whitefly biotype and viruliferous rate detection}

PCR amplification confirmed that all the whiteflies gathered in symptomatic tomato and cucumber plants were B. tabaci Q. The percentage of viruliferous whitefly was $65.0 \%$ and $55.0 \%$, respectively (Fig. 2; Table 3).

\section{Virus detection in plants}

The size of 804 bp based on amplification of CP (coat protein) gene of CCYV was amplified, which revealed that the symptomatic cucumber plants collected in Xinzhuzhen, Yongfazhen and Yazhouzhen and the weeds collected in Yongfazhen of Hainan province was infected by CCYV (Figs. 3 and 5a).

The size of $466 \mathrm{bp}$ based on amplification of heat shock 70-like protein (HSP70h) gene of ToCV was amplified, which showed that the chlorosis tomato plants collected in Xinzhuzhen and Yongfazhen and the weeds collected in Yongfazhen of Hainan province was infected by ToCV (Figs. 4 and $5 b$ ).

\section{Nucleotide sequencing analysis}

The sequencing results were shown in Table 4 . The sequence of the whitefly samples shows a similarity of $99 \%$ with the cytochrome oxidase subunit I (COI) gene of $B$. tabaci Q (KT265875.1). Virus samples in tomato were $100 \%$ similar with the RNA1 of ToCV (KC887999.1), and the virus samples in cucumber showed 97\% similar with the CP gene of CCYV (KX118632.1). The virus samples in weed showed a similarity of $99 \%$ and $97 \%$

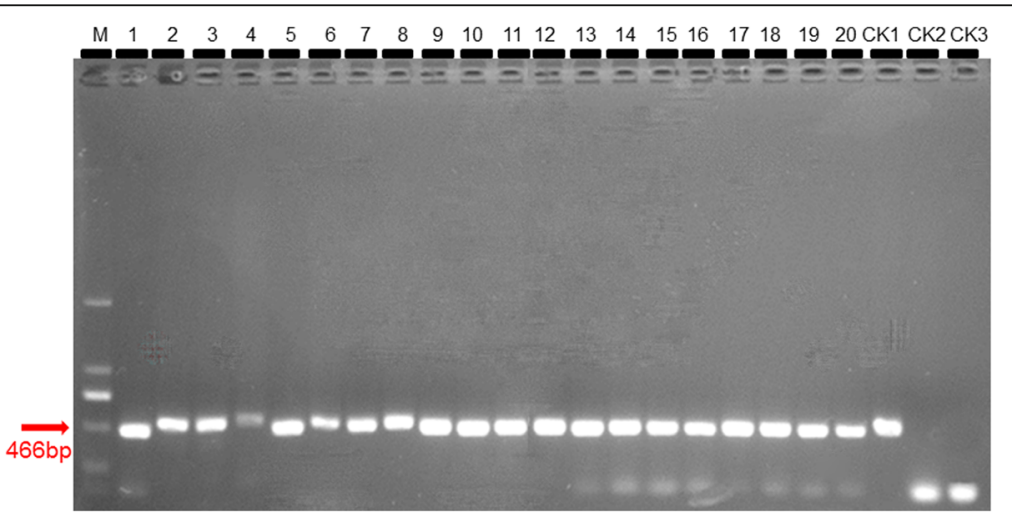

Fig. 4 CCYV detection from cucumber plants. CK1 positive control; CK2 negative control; CK3 black control. The size of 804 bp based on amplification of CP (coat protein) gene of CCYV was used. Results of 20 samples were shown in this figure 


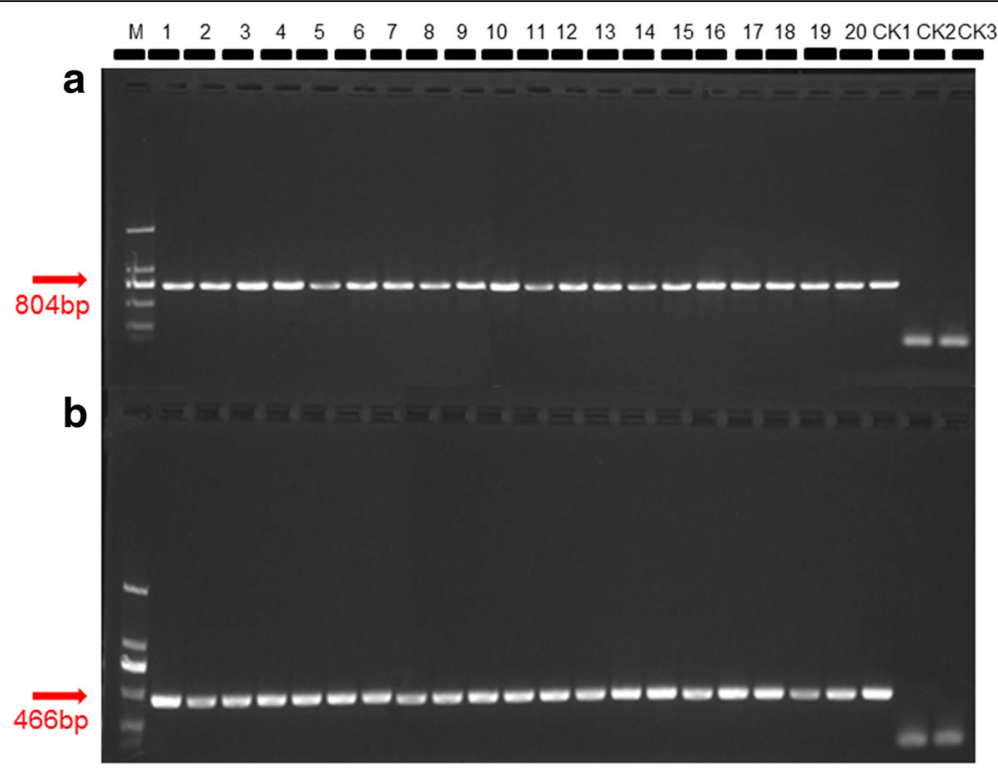

Fig. 5 ToCV and CCYV detection from weeds. a CCYV detection on weeds. b ToCV detection on weeds. CK1 positive control; CK2 negative control; CK3 black control. The size of 804 bp based on amplification of CP (coat protein) gene of CCYV and the size of 466 bp based on amplification of HSP7Oh gene of ToCV were used. Results of 20 samples were shown in figure $\mathbf{a}$ and $\mathbf{b}$

with the RNA1 of ToCV (KC887999.1) and the CP of CCYV (KX118632.1), respectively.

Virus incidence dynamic on tomato, cucumber and weeds Virus incidence dynamic of ToCV on tomato, and the weed, A. philoxeroides and CCYV on cucumber and $A$. philoxeroides changes significantly in the four growth stages of plants (ToCV on tomato: $F_{3,16}=160.737$, $P<0.001 ;$ ToCV on weed: $F_{3,16}=91.701, P<0.001$; CCYV on cucumber: $F_{3,16}=136.496, P<0.001$; CCYV on weed: $\left.F_{3,16}=75.522, P<0.001\right)$. In the transplanting stage, viruliferous rate of both ToCV on tomato and CCYV on cucumber was $0 \%$. However, in the ripening stage, viruliferous rate of ToCV and CCYV on tomato and cucumber was highest, with the viruliferous rate of $77 \%$ and $62.4 \%$, respectively. Viruliferous rate of $\mathrm{ToCV}$ and $\mathrm{CCYV}$ on $A$. philoxeroides showed an opposite trend, which was highest in the transplanting stage of plants and lowest in the ripening stage of plants. In the transplanting stage, the viruliferous rate of ToCV and CCYV on A. philoxeroides was $76.8 \%$ and $66.6 \%$, respectively. In the ripening stage, the viruliferous rate of ToCV and CCYV on A. philoxeroides was $15.4 \%$ and $12.6 \%$, respectively. Notably, the weed A. philoxeroides that was adjacent from tomato and cucumber can carry both ToCV and CCYV at the same time, with the coinfection viruliferous rate of $32.2 \%$ and $6.4 \%$ in the transplanting stage and ripening stage, respectively (Fig. 6).

\section{Discussion}

B. tabaci is a most important insect vector in agricultural areas and has caused great losses in economy and crop production worldwide [25, 33]. The indirect damage caused by virus transmission is much serious than the direct feeding on the host. For example, TYLCV is transmitted by whitefly in a persistent manner, which causes destructive damage in China [9, 34]. In recent years, TYLCV has attracted the large attention and a series of measure has been used to prevent the disease by researchers in China [11,35-37]. However, up to now, we still pay less attention to most of the semi-

Table 4 Nucleotide sequencing analysis of B. tabaci and plant viruses

\begin{tabular}{|c|c|c|c|c|c|c|c|}
\hline Sample & Sequencing description & Accession & $\begin{array}{l}\text { Max } \\
\text { score }\end{array}$ & $\begin{array}{l}\text { Total } \\
\text { score }\end{array}$ & $\begin{array}{l}\text { Query } \\
\text { cover }\end{array}$ & $\begin{array}{l}\mathrm{E} \\
\text { value }\end{array}$ & Identities \\
\hline Tomato & Tomato chlorosis virus isolate ToCV-BJ segment RNA2 & KC887999.1 & 863 & 863 & $45 \%$ & 0.0 & $100 \%$ \\
\hline Cucumber & Cucurbit chlorotic yellows virus isolate GX-BH capsid protein gene & KX118632.1 & 1354 & 1354 & $97 \%$ & 0.0 & $99 \%$ \\
\hline B. tabaci & $\begin{array}{l}\text { Bemisia tabaci biotype Q cytochrome oxidase subunit } 1 \text { (COI) } \\
\text { gene }\end{array}$ & KT265875.1 & 1062 & 1062 & $99 \%$ & 0.0 & $99 \%$ \\
\hline Weed & Tomato chlorosis virus isolate ToCV-BJ segment RNA2 & KC887999.1 & 856 & 856 & $41 \%$ & 0.0 & $99 \%$ \\
\hline Weed & Cucurbit chlorotic yellows virus isolate GX-BH capsid protein gene & KX118632.1 & 1055 & 1055 & $77 \%$ & 0.0 & $97 \%$ \\
\hline
\end{tabular}



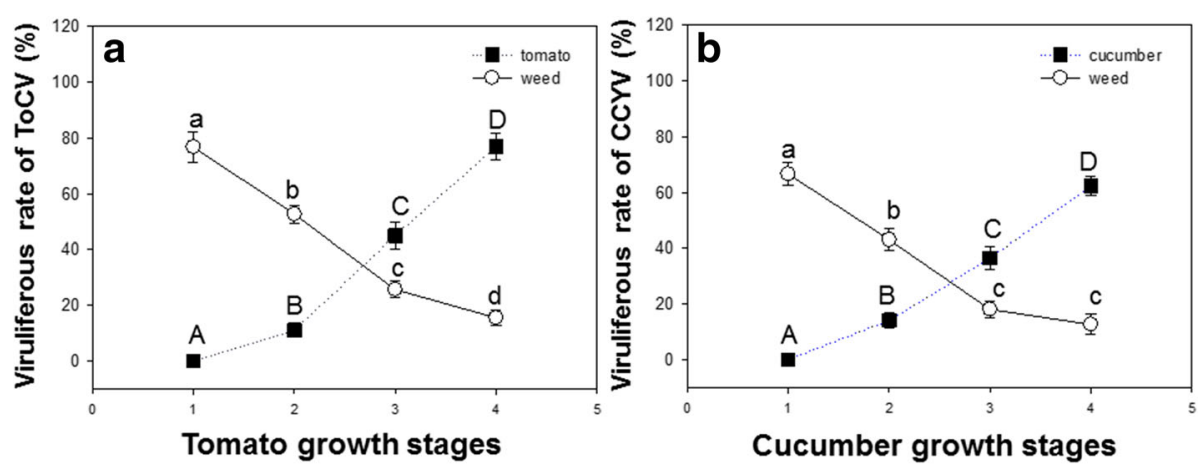

Fig. 6 Virus incidence dynamic on tomato, cucumber and weeds in four of plant growth stages. a Viruliferous rate of ToCV in four of the tomato growth stages. $\mathbf{b}$ Viruliferous rate of CCY in four of the cucumber growth stages. Values are means \pm SE. 1 transplanting stage; 2 seedling stage; 3 flowering stage; 4 ripening stage. On each growth stage, different lowercase letters of a-d indicate significant differences on weed and different uppercase letters of A-D indicate significant differences on plants $(P<0.05)$

persistent viruses transmitted by the whitefly. Furthermore, those plant viruses such as ToCV and CCYV are huge potential crises to agricultural production.

In our research, we found that high density rates of $Q$ at open field in Hainan province and at the same areas we determined that the leaves were infected by $\mathrm{ToCV}$ and CCYV, with the incidence of $69.8 \%$ and $62.6 \%$ on tomato and cucumber plants, respectively. Besides, the viruliferous rate of Q was $65.0 \%$ and $55.0 \%$ on the tomato and cucumber plants, respectively. Plant virus disease prevalence is closely related to the spread of insect vector. Although B. tabaci B has been shown to be an effective vector of ToCV [1], recently, Q has become a major threat to the quality and yields by transmitting ToCV [22]. Besides, B. tabaci Q plays more roles than B in carrying CCYV [38]. In this research, we notice that the prevalence of CCYV in cucumber and ToCV in tomato was high which was consistent with the high viruliferous rate of $\mathrm{Q}$. Therefore we can speculate that high viruliferous rate of $\mathrm{Q}$ may facilitate transmission of ToCV and CCYV.

The weed A. philoxeroides, which was grown near the infected tomato and cucumber, was also infected by ToCV and CCYV. The virus dynamic was then detected on tomato, cucumber and the weeds nearby. In the four growth stages, virus showed a different dynamic on plants and on weeds. On tomato and cucumber plants, viruliferous rate of ToCV and CCYV increased gradually from transplanting stage to ripening stage. On weeds, viruliferous rate of ToCV and CCYV decreased gradually from ripening stage to transplanting stage. Furthermore, both of the ToCV and CCYV were detected on the weed, A. philoxeroides, which is a widely distributed weed in Hainan. To our knowledge, this is the first report of ToCV and CCYV on the weed, $A$. philoxeroides. From our results we can see that the weed, A. philoxeroides is co-infected and may promote the virus transmission, it's a pity that we didn't detect whether the whiteflies were co-infected on weeds, and this needs further confirmation. Notably, Hainan is the mainly vegetable production and breeding center especially for breeding tomato and cucumber in China. In winter season, vegetables in Hainan are transported to all of the north provinces of China because of the low temperature in north provinces. Therefore, the break out of these two viruses may cause fast transmission of ToCV and CCYV to other places via infected seed or viruliferous whiteflies.

\section{Conclusion}

This report firstly shows ToCV and CCYV detected in the same area with a high incidence in Hainan province, with a high viruliferous rate of $\mathrm{Q}$ on infected leaves. Furthermore, the virus dynamic shows a close relationship with the weed nearby, and the weed is infected by both ToCV and CCYV. Hainan is an extremely important vegetable production and seed breeding center in China. If the whitefly can carry these two viruses concurrently, co-infection in their mutual host plants can lead to devastating losses in the near future. Further research should be done to investigate the role of weed in the transmission of virus.

\section{Abbreviations}

CCYV: Cucurbit chlorotic yellows virus; CP: Coat protein; HSP70h: Heat shock 70-like protein; RT-PCR: Reverse transcript-polymerase chain reaction; ToCV: Tomato chlorosis virus; TYLCV: Tomato yellow leaf curl virus

\section{Acknowledgments}

Not applicable.

\section{Funding}

This work was supported by the Special Fund for Agro-scientific Research in the Public Interest (No. 201303028), the National Natural Science Foundation of China (No. 31501643, 31571982 and 31571981), and the Agriculture Research System of China (CARS-25-B-05). The funders had no role in study design, data collection and analysis, decision to publish, or preparation of the manuscript. 


\section{Availability of data and materials}

The datasets used and/or analysed during the current study are available from the corresponding author on reasonable request.

\section{Authors' contributions}

$X T, X B S, X G Z$ and $Y L$ designed the experiments. $X T$ and $X B S$ performed the experiments. XT analyzed the data. XT and XBS wrote the manuscript. DYZ FL, FY and YJZ contributed reagents/materials. All authors read and approved the final manuscript

\section{Ethics approval and consent to participate}

Not applicable.

\section{Consent for publication}

Not applicable.

\section{Competing interests}

The authors declare that they have no competing interests.

\section{Publisher's Note}

Springer Nature remains neutral with regard to jurisdictional claims in published maps and institutional affiliations.

\begin{abstract}
Author details
${ }^{1}$ College of Plant Protection, Hunan Agricultural University, Changsha 410125, China. ${ }^{2}$ Hunan Academy of Agricultural Science, Hunan Plant Protection Institute, Key Laboratory of Pest Management of Horticultural Crop of Hunan Province, No. 726, Yuanda Road, Furong District, Hunan province, Changsha 410125, China. ${ }^{3}$ College of Plant Protection, Yunnan Agricultural University, Yunnan 650201, China. ${ }^{4}$ Institute of virus and biotechnology, Zhejiang Academy of Agricultural Sciences, Hangzhou 310021, China. ${ }^{5}$ Institute of Vegetables and Flowers, Chinese Academy of Agricultural Sciences, Beijing 100081, China. ${ }^{6}$ Department of Entomology, University of Kentucky, S-225 Agricultural Science Center North Lexington, Lexington, KY 40546-0091, USA.
\end{abstract}

Received: 27 March 2017 Accepted: 21 August 2017

Published online: 04 September 2017

\section{References}

1. Wintermantel WM, Wisler GC. Vector specificity, host range, and genetic diversity of Tomato chlorosis virus. Plant Dis. 2006;90:814-9.

2. Brault V, Uzest M, Monsion B, Jacquot E, Blanc S. Aphids as transport devices for plant viruses. C R Biol. 2010;333:524-38.

3. Pinheiro PV, Kliot A, Ghanim M, Cilia M. Is there a role for symbiotic bacteria in plant virus transmission by insects? Curr Opin Insect Sci. 2015;8:69-78.

4. Whitfield AE, Rotenberg D. Disruption of insect transmission of plant viruses. Curr Opin Insect Sci. 2015;8:79-87.

5. Wintermantel WM. Transmission efficiency and epidemiology of criniviruses. In Bemisia: bionomics and management of a global pest. Springer. 2009; 319-331.

6. Navas-Castillo J, Fiallo-Olivé E, Sánchez-Campos S. Emerging virus diseases transmitted by whiteflies. Annu Rev Phytopathol. 2011;49:219-48.

7. Wisler G, Duffus J, Liu HY, Li R. Ecology and epidemiology of whiteflytransmitted closteroviruses. Plant Dis. 1998:82:270-80.

8. De Barro PJ, Liu SS, Boykin LM, Dinsdale AB. Bemisia tabaci: a statement of species status. Annu Rev Entomol. 2011;56:1-19.

9. Pan H, Chu D, Yan W, Su Q, Liu B, Wang S, Wu Q, Xie W, Jiao X, Li R, et al. Rapid spread of Tomato yellow leaf curl virus in China is aided differentially by two invasive whiteflies. PLoS One. 2012;7:e34817.

10. Pan H, Chu D, Liu B, Shi X, Guo L, Xie W, Carriere Y, Li X, Zhang Y. Differential effects of an exotic plant virus on its two closely related vectors. Sci Rep-UK. 2013;3:2230.

11. Shi X, Pan H, Zhang H, Jiao X, Xie W, Wu Q, Wang S, Fang Y, Chen G, Zhou $X$. Bemisia tabaci $Q$ carrying Tomato yellow leaf curl virus strongly suppresses host plant defenses. Sci Rep-UK. 2014:4:5230.

12. Wintermantel WM, Wisler GC, Anchieta AG, Liu HY, Karasev AV, Tzanetakis IE. The complete nucleotide sequence and genome organization of Tomato chlorosis virus. Arch Virol. 2005:150:2287-98.

13. Orfanidou C, Pappi P, Efthimiou K, Katis N, Maliogka V. Transmission of Tomato chlorosis virus (ToCV) by Bemisia tabaci biotype $\mathrm{Q}$ and evaluation of four weed species as viral sources. Plant Dis. 2016;100:2043-9.
14. Fortes IM, Navas-Castillo J. Potato, an experimental and natural host of the crinivirus Tomato chlorosis virus. Eur J Plant Pathol. 2012;134:81-6.

15. García-Cano E, Navas-Castillo J, Moriones E, Fernández-Muñoz R. Resistance to Tomato chlorosis virus in wild tomato species that impair virus accumulation and disease symptom expression. Phytopathology. 2010;100:582-92.

16. Wisler GC, Li RH, Liu HY, Lowry DS, Duffus JE. Tomato chlorosis virus: a new whitefly-transmitted, phloem-limited, bipartite closterovirus of tomato. Phytopathology. 1998;88:402-9.

17. Navas-Castillo J, Camero R, Bueno M, Moriones E. Severe yellowing outbreaks in tomato in Spain associated with infections of Tomato chlorosis virus. Plant Dis. 2000;84:835-7.

18. Gharsallah C, Halima AB, Fakhfakh H, Gorsane F. Insights into the genetic diversity and the phylogenetic analysis of Tunisian isolates of Tomato chlorosis virus. Phytoparasitica. 2014;43:87-96.

19. Moodley V, Gubba A, Mafongoya P. Occurrence of Tomato chlorosis virus (ToCV) on Datura stramonium near tomato crops (Solanum lycopersicum) in South Africa. Plant Dis. 2016:

20. Kil EJ, Lee YJ, Cho S, Auh CK, Kim D, Lee KY, Kim MK, Choi HS, Kim CS, Lee S. Identification of natural weed hosts of Tomato chlorosis virus in Korea by RT-PCR with root tissues. Eur J Plant Pathol. 2015;142:419-26.

21. Zhao LM, Li G, Gao Y, Liu YJ, Sun GZ, Zhu XP. Molecular detection and complete genome sequences of Tomato chlorosis virus isolates from infectious outbreaks in China. J Phytopathol. 2014;162:627-34.

22. Guevara-Coto JA, Barboza-Vargas N, Hernandez-Jimenez E, Hammond RW, Ramirez-Fonseca P. Bemisia tabaci biotype Q is present in Costa Rica. Eur J Plant Pathol. 2011:131:167.

23. Tsai W, Shih S, Green S, Hanson P, Liu H. First report of the occurrence of Tomato chlorosis virus and Tomato infectious chlorosis virus in Taiwan. Plant Dis 2004; 88:311-311.

24. Zheng HX, Xia JX, Zhou XM, Zhang YJ. Be on alert of rapid diffusion of Toamto chlorosis virus transmitted by whitefly in China. China Vegetables. 2016; 22-26 (Chinese with English abstrct).

25. Abrahamian PE, Abou-Jawdah Y. Whitefly-transmitted criniviruses of cucurbits: current status and future prospects. Virus disease. 2014;25:26-38

26. Orfanidou C, Maliogka V, Katis N. First report of Cucurbit chlorotic yellows virus in cucumber, melon, and watermelon in Greece. Plant Dis 2015; 99 : 734-734.

27. Okuda M, Okazaki S, Yamasaki S, Okuda S, Sugiyama M. Host range and complete genome sequence of Cucurbit chlorotic yellows virus, a new member of the genus crinivirus. Phytopathology. 2010;100:560-6.

28. Zeng R, Dai FM, Chen WJ, Lu JP. First report of Cucurbit chlorotic yellows virus infecting melon in China. Plant Dis 2011; 95:354-354.

29. Hamed K, Menzel W, Dafalla G, Gadelseed AMA, Winter S. First report of Cucurbit chlorotic yellows virus infecting muskmelon and cucumber in Sudan. Plant Dis 2011; 95:1321-1321.

30. Orfanidou C, Maliogka VI, Katis NI. First report of Cucurbit chlorotic yellows virus in cucumber, melon, and watermelon in Greece. Plant Dis 2014; 98: 1446-1446.

31. Bananej K, Menzel W, Kianfar N, Vahdat A, Winter S. First report of Cucurbit chlorotic yellows virus infecting cucumber, melon, and squash in Iran. Plant Dis 2013; 97:1005-1005.

32. Chu D, Wan FH, Zhang YJ, Brown JK. Change in the biotype composition of Bemisia tabaci in shandong province of China from 2005 to 2008. Environ Entomol. 2010;39:1028-36.

33. Brown JK, Czosnek H. Whitefly transmission of plant viruses. Adv Bot Res. 2002;36:65-76.

34. Liu B, Preisser EL, Chu D, Pan H, Xie W, Wang S, Wu Q, Zhou X, Zhang Y. Multiple forms of vector manipulation by a plant-infecting virus: Bemisia tabaci and Tomato yellow leaf curl virus. J Virol. 2013;87:4929-37.

35. Shi X, Pan H, Xie W, Wu Q, Wang S, Liu Y, Fang Y, Chen G, Gao X, Zhang Y. Plant virus differentially alters the plant's defense response to its closely related vectors. PLoS One. 2013;8:e83520.

36. Fang $Y$, Jiao $X$, Xie W, Wang $S$, Wu Q, Shi X, Chen G, Su Q, Yang X, Pan H. Tomato yellow leaf curl virus alters the host preferences of its vector Bemisia tabaci. Sci Rep-UK. 2013;3:2876.

37. Ning W, Shi X, Liu B, Pan H, Wei W, Zeng Y, Sun X, Xie W, Wang S, Wu Q. Transmission of Tomato yellow leaf curl virus by Bemisia tabaci as affected by whitefly sex and biotype. Sci Rep-UK. 2015;5:10744.

38. Lu SH. Li JH, Wang XL, Song DY, Bai R, Shi Y, Gu QS, Kuo YW, Falk BW. Yan FM A semipersistent plant virus differentially manipulates feeding behaviors of different sexes and biotypes of its whitefly vector Viruses. 2017;9:4. 